\title{
LA CONSTRUCCIÓN DE LA IDENTIDAD PROFESIONAL DEL PROFESORADO DE EDUCACIÓN ESPECIAL DE ENSEÑANZA SECUNDARIA EN ITALIA. UN ESTUDIO EN LA ZONA DE NÁPOLES
}

\author{
THE CONSTRUCTION OF A PROFESSIONAL IDENTITY FOR SPECIAL NEEDS \\ TEACHERS IN THE ITALIAN HIGH SCHOOL SYSTEM. A STUDY ON THE NAPLES \\ AREA
}

\author{
Maura Striano \\ Full professor of Pedagogy \\ Department of Humanities \\ University of Naples Federico II \\ Elisabetta Grieco \\ Phd in Psychological and Pedagogical Sciences \\ University of Naples Federico II
}

Fecha de recepción: 12 de junio de 2013

Fecha de aceptación: 16 de junio de 2014

Fecha de publicación: 30 de junio de 2014

\section{RESUMEN}

Desde 1977 y con la ley 517/77, los estudiantes con necesidades especiales de movilidad reducida han sido incluidos en las clases regulares en el sistema escolar italiano. Esto ha sucedido con el apoyo de profesores especializados, a quienes se les ha otorgado la responsabilidad de administrar el proceso de inclusión de los estudiantes en la clase y de apoyar a los otros profesores en la realización de esta actividad. No obstante, aun cuando la normativa hace hincapié en la participación de todos los docentes en el proceso de inclusión de los estudiantes con discapacidad, así como en la participación de los profesores especializados en todas las actividades de la clase, a lo largo de los años, en todos los días y en las actividades educativas de rutina, la maestra de necesidades especiales sigue jugando un papel secundario en la escena educativa en comparación con el resto de profesores a cargo de las actividades curriculares.

De acuerdo con los indicadores del Índice de Inclusión observamos, pues, que la condición del maestro de necesidades especiales es de hecho una condición de exclusión, en un contexto de práctica profesional que pretende y se esfuerza por ser incluyente. Esta condición produce la paradoja de que el maestro de necesidades especiales, que debería fomentar y apoyar procesos de inclusión de los estudiantes con discapacidad, queda exclude/a y segregado/a de las actividades del plan de estudios que involucran a toda la clase y experimenta formas de exclusión dentro y fuera del sistema escolar.

Por esta razón los profesores de necesidades especiales tienen una percepción confusa de su identidad profesional, de su papel y su función dentro de la comunidad de profesionales de la educación especial.

Dentro de este marco, este trabajo presenta un estudio de Doctorado de tres años en el área de Nápoles, cuyo objetivo es identificar y explorar los elementos que, combinados entre sí, conforman el perfil profesional del maestro de necesidades 
especiales en el sistema de enseñanza secundaria y las conexiones entre dichos elementos, incluyendo cómo éstos dan forma a la práctica profesional.

Palabras clave: Perfil profesional; Identidad profesional; Rol y competencias; Profesorado de necesidades especiales.

\section{ABSTRACT}

Since 1977 and the law 517/77, disabled and special needs students have been included in regular classes within the Italian school system. This has happened with the support of specialized teachers, who have been given the responsibility of managing the process of inclusion of the students in the class and of supporting the other teachers in undertaking this activity. Nonetheless, even if the regulations emphasizes the involvement of all teachers in the inclusion process of disabled students as well as the involvement of the specialized teachers in all class activities, over the years, in everyday and routine educational activities, the teacher for special needs has been widely acknowledged as a secondary actor in the educational scene in comparison with the other teachers in charge of curricular activities.

According to the indicators of the Inclusion Index we note therefore that the condition of the teacher for special needs is indeed a condition of exclusion, within a context of a professional practice which claims and strives to be inclusive. This condition produces the paradox that the teacher for special needs, who should promote and support inclusive processes for disabled students, is herself/himself excluded and segregated from the curricular activities involving the whole class and experiences forms of exclusion inside and outside the school system.

For this reason the teachers for special needs have a confused perception of their professional identity, of their role and their function within the professional community of special needs education.

Within this framework the paper presents a three years Phd study in the Naples area, aimed at identifying and exploring the elements which, combined together, shape the professional profile of the teacher for special needs in the secondary school system and the connections between those elements, including how such elements shape professional practice.

Key words: Professional profile; Professional identity; Role and competences; Teachers for special needs.

\section{THE CONTEXTS}

In Italy the seventies were the starting point for an educational and legislative process which has accompanied the progressive inclusion of the disabled students until then segregated in both "special" institutions and schools or in differential classes, thereby marginalized and prevented from participating in the civil and social life of the country?.

\footnotetext{
1 The steps towards the social and educational inclusion of disabled people have been regulated over the years by the following Laws: Law 30th March 1971, n. 118 "Nuove forme in favore degli invalidi civili e dei mutilati"; Ministry of Public Instruction "Relazione conclusiva della Commissione Falcucci concernente i problemi scolastici degli alunni handicappati" of 1975; Law 4th August 1977, n. 517 "Norme sulla valutazione degli alunni e sull'abolizione degli esami di riparazione nonché altre
} 
The Law n. 517, issued on 4th August 1977 is the starting point of a "Copernican revolution" which has guaranteed to disabled students the right to fully participate in school life and to teachers for special needs the possibility to perform their professional role ${ }^{2}$ within the public school system as specialized teachers in charge of the inclusion processes undertaken inside the school and the classes ${ }^{3}$. This is what is suggested in the regulations and what has been realized through many excellent initiatives considered as models of good practice. Nonetheless, in the following thirty years, in everyday educational activities, teachers for special needs have been widely acknowledged as secondary actors in the educational scene in comparison with the other teachers in charge of curricular activities. Their role has therefore been confined to the task of "taking care", alone, of only the students with special needs in spite of the legal requirements, which emphasize the involvement of all teachers in the inclusion process as well as the involvement of specialized teachers in all class activities.

This is particularly true at the high school level where special needs students need to be supported with individualized and personalized learning projects, which in theory should be developed by all the class teachers but in practice have been considered as a "job for" the teachers for special needs.

We therefore arrive at the paradox that the teacher for special needs, who should promote and support inclusive processes for disabled students, is herself/himself excluded and segregated from the curricular activities involving the whole class and experiences forms of exclusion inside and outside the school system.

norme di modifica dell'ordinamento scolastico"; Law 5th February 1992, n. 104 "Legge quadro per l'assistenza, l'integrazione sociale e i diritti delle persone handicappate"; Decree of the President of the Republic 24th February 1994 "Atto di indirizzo e coordinamento relativo ai compiti delle unità sanitarie locali in materia di alunni portatori di handicap"; 4th August 2009 "Linee guida per l'integrazione scolastica degli alunni con disabilità"; Law 8th October 2010, n. 170 "Nuove norme in materia di disturbi specifici di apprendimento"; Decree of the Ministry of Education and Research, 27th December 2012, Strumenti di intervento per gli alunni con Bisogni Educativi Speciali e organizzazione territoriale per l'inclusione scolastica.

2 The guidelines for the integration of disabled students indicated in the above cited Law n. 517/1977: point out that it is possible to promote inclusive educational activities within the class and the school for groups of students as well as individualized educational activities according to the needs of individual students with the support of specialized teachers and an interdisciplinary professional team of experts.

${ }^{3}$ According to d'Alonzo, this is the starting point of a deep change in the Italian school system which has produced innovation in educational and teaching practices, interdisciplinary and inter-professional work, and institutional networking (Canevaro, d'Alonzo, lanes, \& Caldin, 2011). 
This situation has been highlighted by a series of studies and research projects at a national level which have pointed out that it is extremely difficult to develop an effective system for the integration/inclusion of the students with special needs if the teachers are not clearly identified and used as system resources as they should be.

For this reason the teachers for special needs have a confused perception of their professional identity, of their role and their function within the professional community of special needs education.

It is therefore extremely important to explore this perception in depth, helping teachers for special needs in reflecting on their own identity and role at various levels, according to the different conditions they experiment within different territorial contexts.

This requires the development of comparative study of the perceptions and the positions of teachers for special needs focusing on different territorial areas in order to: a) identify analogies and differences in the professional profiles and roles of the teachers for special needs; $b$ ) to highlight their motivations, perceptions, practices, relationships with the other teachers; c) to re-define their role within the educational contexts and the local and the national communities of practice.

\section{THE PROFESSIONAL PROFILE OF THE TEACHER FOR SPECIAL NEEDS IN THE SECONDARY SCHOOL SYSTEM. A STUDY IN THE NAPLES AREA.}

Within the above mentioned framework at the University of Naples Federico II we have designed and carried on a three years exploratory study within a Phd program, involving 10 secondary schools in the Naples area (4 technical schools, 3 vocational schools, and 3 high schools) and 161 teachers for special needs.

The purpose of the exploratory study was: a) to identify and investigate the elements that form the professional profile of the teacher for special needs in the secondary school system within a specific geographical context; b) to explore the connections between those elements and their impact on professional practice.

The research questions which have provided the study with its epistemological framework are the following:

- What is the professional identity (in terms of knowledge and competences) of the teacher for special needs in the 
secondary school and how is this professional identity acted out within a specific cultural and geographical context?

- What are the practices that characterize the teacher for special needs?

- What elements and/or actors in the school system have an impact on her/his role and practice?

- What are her/his training and professional development needs? required:

The complexity of the phenomenon explored in the study has

a) an organization of the research process in two phases, a macro-phase (with an explorative purpose and quantitative dimension) and a micro phase (with a hermeneutic purpose and a qualitative dimension);

b) the use of a quali/quantitative methodology.

The quantitative dimension (cfr. Gattico \& Mantovani, 1998; Viganò, 2002) relevant for the first part of the first phase of the study, has allowed us, through the use of a statistical procedure of data analysis 4 to identify the data and variables which define the professional profile of the teacher for special needs. The qualitative dimension involved both in the first and second phase of the study has allowed us to capture elements that cannot be measured but are relevant in the representation, perception, and interpretation of the professional role within multiple contexts (cfr. Mantovani, 1998).

\subsection{The macro -phase}

The exploration of the professional profile within the macro-phase has been conducted with the test battery M.E.S.I. (cfr. Moè, Pazzaglia \& Friso, 2010) 5 together with an open questions questionnaire.

\footnotetext{
4 The data collected with the MESI battery have been analyzed with the software SPSS for statistical analysis.

5 The M.E.S.I. battery is organized in 7 sections. A registry sheet: (ANAGR): which collects general information regarding the status of the teacher (age, sex, degree, number of years of teaching, institution, disciplinary area, tenured or non-tenured position, home location, location of the school); a Professional Satisfaction scale (SOD) composed of 5 items; an Educational practices scale (PRASSli) composed of 25 items; an Emotional scale referring to the emotions related to the perception of the role and of the emotions experienced while teaching (EMOZ-role and EMOZ-teaching) composed of 30 items, each of which identifying positive and negative emotions according to a scale of frequency; a Teaching Strategies Scale (STRAT) composed of 30 items which identify the use of a specific strategy according to a scale of frequency; a Professional Self-Efficacy scale (AUTOEFF) composed of 24 items in reference to which the teacher has to rank her/his level of efficacy on a 9 point scale; and an Incrementality Scale (INCR) composed of 16 items according to which the teacher
} 
The M.E.S.I. battery has been conceived as a metacognitive tool to support teachers' professional development and is useful for the collection of general information regarding the teachers' status, the professional satisfaction perceived, the frequency of use of a series of practices and strategies, the positive and negative emotions experienced in relation to one's own professional role and professional activity, and the perception of self-efficacy and self-incrementally in a series of areas and situations in teaching and class management. In order to use this with teachers for special needs the battery has been modified in the registry sheet with a focus on the students rather than on the class in the sections related to teaching practices, strategies, selfefficacy and self-incrementally.

The open questions questionnaire has been developed in order to identify the essential structures and the critical points regarding motivation towards the professional choice, and all the aspects that are factors in the experiences and routines of the professional practice of the teachers for special needs. This has offered us the opportunity to collect data in a more aggregated form (Atkinson, 1998).

For these reasons the teachers were asked to answer the following questions:

1. What has motivated you to become a teacher for special needs?

2. Can you narrate a significant event that has occurred during your professional experience describing the context and actors.

3. Lessons learned ....

The questionnaire has highlighted three areas of interest: motivation towards professional choice, professional experience and learning within professional practice contexts.

The data collected and the results achieved within the macro phase of the study have helped us to acquire a general understanding of the strengths and weaknesses of the teachers for special needs in the secondary school system with a particular focus on a specific geographical area.

has to indicate how she/he believes a specific ability/competence can be incremented on a 9 point scale. 


\section{Articulation of the research pathway within the Macro - Phase}

1. Selection of the research tools (M.E.S.I battery and open questions questionnaires)

2. Design and construction of the open questions questionnaire.

3. Construction of a network of informal contacts and relationships in order to select the schools to be involved in the study.

4. Selection of a number of high schools potentially interested in paticipating to the research.

5. First contact (by phone and/or by e- mail) with key institutional actors (principal, teachers involved in the working group for inclusion; teachers for special needs) to introduce the research.

6. First meeting with the principal and the working group for inclusion to: a) explain the aims of the research; b) ask for the authorization to deliver the MESI battery and the open questions questionnaire to the teachers for special needs working in the school; c) describe and explain the procedures for the collection, analysis and use of the data.

7. Delivery of the MESI battery and of the questionnaire.

8. Collection of the MESI battery and of the questionnaire

9. Analysis and interpretation of the data collected through the MESI battery.

10. Individual analysis of the open questions questionnaires (internal researcher).

11. Collective analysis and discussion of the open questions questionnaire (internal researcher/external researchers).

12. Interpretation and discussions of the results.

The selection of the participants to the macro - phase of the research has required the development of a series of informal contacts in order to select in the Naples areas the secondary schools potentially interested in participating to the research.

For this reason we have used an "opportunistic", "snow ball", "progressive" sampling procedure (Miles \& Huberman, 1994, Merrill, \& West, 2012). It is "opportunistic" sampling because the personal knowledge with some teachers for special needs has made it possible to contact the principals and the coordinators in order to explain the guidelines and purposes of the research, ask the authorization to deliver the materials and indicate the anonymous procedures of data collection; it is a "snow ball" or "progressive" sampling because the principals and teachers for special needs involved in the research have been asked to indicate other principals and teachers willing to participate.

10 schools out of the 21 contacted have participated to the 
research:

- 4 technical schools;

- 3 vocational schools;

- 3 lyceums.

Of the 161 M.E.S.I. batteries delivered 100 have been completely filled in and collected; of the 161 open questions questionnaires delivered 75 have been filled in (even if not completely) and collected's. Not all the participants have answered to all the questions. In particular only 75 teachers for special needs have answered to the question What has motivated you in becoming a teacher for special needs?; to the question Can you narrate a significant event occurred during your professional experience describing the context and the actors? Have answered 56 teachers; to the following question, Lesson learned...have answered only 47 teachers (see table 1 and table 2).

\begin{tabular}{|l|c|c|}
\hline \multicolumn{1}{|c|}{ Secondary Schools } & $\begin{array}{c}\text { M.E.S.I. batteries } \\
\text { delivered }\end{array}$ & $\begin{array}{c}\text { M.E.S.I. batteries } \\
\text { filled in and } \\
\text { collected }\end{array}$ \\
\hline 1. Istituto Tecnico "Giordani", & 10 & 8 \\
\hline 2. Istituto Tecnico "Serra" & 15 & 10 \\
\hline 3. Istituto Tecnico "De Cillis" (Ponticelli) & 3 & 3 \\
\hline 4. Istituto Tecnico "Striano" & 7 & 5 \\
\hline 5. Istituto Professionale "Fortunato" & 43 & 19 \\
\hline 6. Istituto Professionale “ Esposito & 20 & 11 \\
\hline Ferraioli" & 38 & 27 \\
\hline 7. Istituto Professionale" Rossini" & 10 & 6 \\
\hline 8. Liceo “Villari" & 5 & 5 \\
\hline 9. Liceo "Campanella" & 10 & 6 \\
\hline 10. Liceo "Comenio" & 161 & 100 \\
\hline Total & & \\
\hline
\end{tabular}

Table 1

The results of the macro phase of the study, have helped us to identify the typical professional profile of the teacher for special needs : a woman (89.1 \%), with a tenured position (76.6 \%), average age between 41 and $\mathbf{4 5}$ years (30.2\%), with a Bachelor's degree in

6 See tables 1 and 2. 
Humanities (71.4\%), employed in a professional school (55.7\%), with 16 to 25 years of previous teaching experience (33\%), not fully satisfied with her/his profession, but experiencing positive emotions with regard to professional practice and role and a high level of self-efficacy, and showing a capability to use differentiated teaching practices and strategies.

\begin{tabular}{|c|c|c|}
\hline Secondary Schools & $\begin{array}{c}\text { Open questions } \\
\text { questionnaires } \\
\text { delivered }\end{array}$ & $\begin{array}{l}\text { Open questions } \\
\text { questionnaires filled } \\
\text { in }\end{array}$ \\
\hline 1. Istituto Tecnico "Giordani", & 10 & 4 \\
\hline 2. Istituto Tecnico "Serra" & 15 & 9 \\
\hline 3. Istituto Tecnico "De Cillis" (Ponticelli) & 3 & 3 \\
\hline 4. Istituto Tecnico "Striano" & 7 & 0 \\
\hline 5. Istituto Professionale "Fortunato" & 43 & 11 \\
\hline $\begin{array}{l}\text { 6. Istituto Professionale "Esposito } \\
\text { Ferraioli" }\end{array}$ & 20 & 7 \\
\hline 7. Istituto Professionale " Rossini” & 38 & 26 \\
\hline 8. Liceo "Villari" & 10 & 5 \\
\hline 9. Liceo "Campanella" & 5 & 4 \\
\hline 10. Liceo "Comenio" & 10 & 6 \\
\hline Total & 161 & 75 \\
\hline
\end{tabular}

Teachers for special needs are fully aware of the importance of practice and professional development but are not likely to be involved in professional development processes aimed at supporting changes and instrumentality in their practice.

According to these data we can identify strengths in the field of professional action and practices which are rich and differentiated, and in the emotional sphere, which indicates the presence of effective cognitive and emotional resources useful for coping with the challenges of professional life. On the other hand, we can identify weaknesses in the area related to personal fulfillment and satisfaction regarding one's own professional profile, and in the area related to incrementality.. These results show a higher risk of burn-out for teachers for special needs and the tendency not to consider the possibility of incrementing one's own professionality through practice and professional development. 


\begin{tabular}{|c|c|c|c|c|}
\hline Tab. G & Average & S.D. & $\begin{array}{l}\text { Normative values } \\
\text { Average and SD } \\
\text { (in parenthesis) }\end{array}$ & Position \\
\hline Satisfaction_tot & 4,71 & 1,023 & $4,99(1,10)$ & Under the average \\
\hline Practice_tot & 4,27 & 0,274 & $4,08(0,40)$ & Above the average \\
\hline Strategies_tot & 3,87 & 0,462 & $3,58(0,59)$ & Above the average \\
\hline Self efficacy_tot & 7,05 & 1,02 & $7,03(1,06)$ & Above the average \\
\hline Incrementality_tot & 6,72 & 1,49 & $7,12(1,20)$ & Under the average \\
\hline $\begin{array}{l}\text { Emotion_Role } \\
\text { positive }\end{array}$ & 3,41 & 0,664 & $3,21(0,71)$ & Above the average \\
\hline $\begin{array}{l}\text { Emot_Role } \\
\text { negative }\end{array}$ & 1,81 & 0,64 & $2,01(0,59)$ & Under the average \\
\hline $\begin{array}{l}\text { Emot_Teaching. } \\
\text { Positive }\end{array}$ & 3,65 & 0,59 & $3,50(0,52)$ & Above the average \\
\hline $\begin{array}{l}\text { Emot._Teaching. } \\
\text { Negative }\end{array}$ & 1,70 & 0,52 & $1,86(0,52)$ & Under the average \\
\hline
\end{tabular}

Moreover, with reference to the essential structure and the critical points referring to the motivation towards this specific professional choice (b.1) as well as to the aspects referring to routines and experience of professional practice, we can say that the professional choice is mostly determined, first, by the necessity to find any kind of teaching job (because in Italy there are more possibilities of employment in the public schools for teachers for special needs) and, secondly, but less significantly, by a motivation towards a "caring" profession. Once involved in the professional role, the teachers, through experience and the development of a significant educational relationship with their students, come to reflect on their professional identity and become engaged in a conscious critical thinking regarding their own profession, thereby arriving at a profound re-framing of their meaning perspectives. The professional identity of the teacher for special needs is deeply influenced by external environmental factors as well as by individual and collective social representations (cfr. Farr \& Moscovici, 1984) which appear to regulate the actions and practices within professional contexts so that teachers often negotiate their own role with the professional context they are situated in:

1. the repertory of didactic strategies used within the professional practice is wide and complex, but what is essential is networking. 
2. teachers are continuously committed to coping with the suffering of disabled students and their families.

The following is an example of the analysis procedure referred to the motivation dimension.

\begin{tabular}{|c|c|c|c|}
\hline Text unit & $\begin{array}{c}\text { Syntetic } \\
\text { description }\end{array}$ & Label & Category \\
\hline $\begin{array}{l}\text { "When I was an university student I } \\
\text { wanted to become a researcher, but } \\
\text { once I graduated I realized that it was } \\
\text { very difficult to succeed in this project. } \\
\text { One of the job opportunities I had } \\
\text { was teaching and a colleague } \\
\text { suggested to get a specialization to } \\
\text { support disabled students. I have } \\
\text { always been sensitive to diversity in } \\
\text { all senses and to the rights of } \\
\text { minorities I have accepted this } \\
\text { suggestion. So I have become a } \\
\text { teacher for special needs. At the } \\
\text { beginning I was very motivated and } \\
\text { believed, ingenuously, that also the } \\
\text { other teachers were sensitive to the } \\
\text { different needs of the students but } \\
\text { unfortunately it is not always the case. } \\
\text { Experience had diminished the initial } \\
\text { enthusiasm" (Questionnaire } n^{\circ} 74 \text {, } \\
\text { question n' } 1 \text { ). }\end{array}$ & $\begin{array}{l}\text { The teacher } \\
\text { describes the } \\
\text { lack of the } \\
\text { possibilities to } \\
\text { succeed in her } \\
\text { original } \\
\text { project. }\end{array}$ & $\begin{array}{l}\text { Reflects of } \\
\text { the } \\
\text { opportunity } \\
\text { to get an } \\
\text { alternative } \\
\text { job. }\end{array}$ & $\begin{array}{c}\text { Job } \\
\text { opportunity }\end{array}$ \\
\hline $\begin{array}{l}\text { "At the beginning I had been } \\
\text { motivated in becoming a teacher for } \\
\text { special needs because it was very } \\
\text { difficult to become an ordinary } \\
\text { teacher for my discipline, so I had to } \\
\text { find an alternative pathway. My initial } \\
\text { experiences have been not very } \\
\text { fulfilling.[...]" } \\
\text { (Questionnaire } n^{\circ} 89 \\
\text { question } n^{\circ} 1 \text { ). }\end{array}$ & $\begin{array}{l}\text { The teacher is } \\
\text { frustrated } \\
\text { because } \\
\text { cannot teach } \\
\text { her discipline }\end{array}$ & $\begin{array}{l}\text { Reflects on } \\
\text { the } \\
\text { uncertainty } \\
\text { of her } \\
\text { professional } \\
\text { future }\end{array}$ & $\begin{array}{c}\text { Job } \\
\text { opportunity. }\end{array}$ \\
\hline
\end{tabular}

What we have here described has been the starting point for an exploration, during the micro phase of the research, of areas of interest such as: professional epistemology (in terms of knowledge and competences); professional practice; and elements and actors within 
the school system influencing the role and professional agency; and the training and professional development needs of the teachers for special needs in secondary schools in the Naples area. (See tables A; B; C; D; E, F, G).

\begin{tabular}{|c|c|}
\hline $\begin{array}{c}\text { Tab. B } \\
\text { Sex }\end{array}$ & $\begin{array}{c}\text { Valid } \\
\text { percentage }\end{array}$ \\
\hline M & 10,9 \\
\hline F & 89,1 \\
\hline Total & 100 \\
\hline
\end{tabular}

\begin{tabular}{|c|c|}
\hline $\begin{array}{c}\text { Tab. C } \\
\text { Bachelor degree }\end{array}$ & $\begin{array}{c}\text { Valid } \\
\text { percentage }\end{array}$ \\
\hline Humanistic & 71,4 \\
\hline Scientific & 28,6 \\
\hline Total & 100 \\
\hline
\end{tabular}

\begin{tabular}{|c|c|}
\hline $\begin{array}{c}\text { Tab. D } \\
\text { Kind of school }\end{array}$ & $\begin{array}{c}\text { Valid } \\
\text { percentage }\end{array}$ \\
\hline Technical & 26,8 \\
\hline Lyceum & 17,5 \\
\hline Vocational & 55,7 \\
\hline Totale & 100 \\
\hline
\end{tabular}

\begin{tabular}{|c|c|}
\hline $\begin{array}{c}\text { Tab. E } \\
\text { Years of teaching }\end{array}$ & $\begin{array}{c}\text { Valid } \\
\text { percentage }\end{array}$ \\
\hline$<9$ & 20.9 \\
\hline $9-15$ & 30,8 \\
\hline $16-25$ & 33,0 \\
\hline$>25$ & 15,4 \\
\hline Total & 100 \\
\hline
\end{tabular}

\begin{tabular}{|c|c|}
\hline Tab. F Tenure & $\begin{array}{c}\text { Valid } \\
\text { percentage }\end{array}$ \\
\hline Yes & 76,6 \\
\hline No & 23,4 \\
\hline Total & 100 \\
\hline
\end{tabular}

\subsection{The micro phase}

The results of the macro phase have allowed us to head towards the micro phase of the study, involving the design, delivery, analysis and interpretation of a narrative interview to a number of selected teachers among those who had participated in the first phase.

\section{Articulation of the research pathway in the Micro -Phase}

1. Design of the narrative interview

2. Involvement of the participants

3. Collection of th narrative interview

4. Reading and analysis of the narrative interview (internal researcher)

5. Reading and analysis of the narrative interview (internal researcher/external researchers)

6. Interpretation of the results.

The second phase of the study has involved 11 teachers for special needs $(9$ female, 2 male, 7 tenured and 4 non-tenured, aged between 
35 and 54 years old and belonging to all the four disciplinary areas available in the Italian school system : AD01 (Science), AD02 (Humanities, Language, and Music); AD03 (Area Techniques and Arts); and AD04 (Psycho-motor area). The outcomes from this phase have helped us to define an organized and complex professional profile which is constructed around a series of interconnected elements:

- professional identity (identified as the area within which the teacher defines for himself/herself and for other people "who they are and what they can do in terms of knowledge and competences" );

- role (the focus is on the tasks, that is "what they do and how they play out their professional identity within a specific context" );

- professional practice;

- training and professional development needs.

On the basis of the answers to the open questions questionnaires we have chosen to use a narrative interview on the basis of the following theoretical premises:

1. narrative is a structure useful for organizing our knowledge and experience as it activates and leads a search for meaning within a range of multiple possible meanings (Bruner, 1988, 2001);

2. narrative is a privileged research tool to access and understand the professional epistemology and the "personal practical knowledge" of teachers (cfr. Connelly \& Clandinin, 1997);

3. the narrative interview allows people to talk freely about their own experience, organizing their own experience into a narrative (Alheit \& Bergamini, 1996);

4. the act of narration is a creation of meaning since the respondents are invited to narrate episodes, conflicts, solutions, emotions, and decisions which have brought into question their own values and meaning perspectives (cfr. Atkinson, 2002);

5. through narrative thinking experience takes form.

The narrative interview, which we can consider as a situation of guided interaction with the support of an interviewer who stimulates and facilitates the description of individual experience (Sità, 2012), is a valid tool useful to focus attention on the meanings that teachers give to their own stories, events, actions, behaviors and subjective states. Narrative can therefore be considered as an epistemic work on the educational experience which allows us to have access to the epistemic structure of educational experience at three levels: 1. a recovery of the forms and 
patterns through which the experience is understood and interpreted by the actors involved in it, which allows us to access the mental states and the cognitive processes at stake; 2 . a recovery of the forms and patterns through which new knowledge structures- more or less conscious and explicit- are constructed and used within the experience; and 3. a recovery of the knowledge interests underlying actions, thoughts, and knowledge construction within the experience (Striano, 2005).

The above mentioned theoretical guidelines, together with the results achieved in the first part of the study, have provided us with a "map" which has guided us in the construction of the narrative interview in order to grasp:

a) the meanings through which teachers for special needs build up their professional profile;

b) the practices directing their professional development;

c) the elements and actors in the school system that impact on the teacher's role and on professional practice;

d) the training and professional development needs of the teachers.

The interview is structured along a track focused on pre-defined thematic areas and is composed of a series of questions already structured but open to new issues and unexpected themes introduced by the respondents.. It is therefore a semi-structured interview, focused on and directed at the collection of descriptions of professional experiences through five main questions:

1. How long have you been working as a teacher for special needs and how did you start your professional pathway?

2. Can you tell me something about your working day? What do you do when you enter the classroom?

3. Can you tell me something about how you feel when you teach and which are the main difficulties that you encounter?

4. How would you describe your relationships with the students, their families, your colleagues and the overall professional environment (the principal, administrative staff, janitors, and physical environment)?

5. How far do you believe that your professionality can be incremented and through which opportunities and resources?

The interview is composed of two sections: the first section is devoted to the transcription of information regarding the respondent 
concerning age, sex, institution, years of teaching, degree and previous professional experience; and the second is devoted to the transcription of the interview made by the researcher, together with field notes and reflections.

From the textual analysis of the narrative interviews some "extended and common qualities" have emerged. These qualities characterize the professional experience of the teachers for special needs.

On these basis we have identified 12 categories: 1. Professional identity, 2. Role, 3. Relationship between personal identity and professional identity, 4. Feeling $s$ and emotions, 5. Motivation, 6. Representations and linguistic uses, 7. Professional practice, 8. Reflective practice, 9. Relationship with the families, 10. Relationship with colleagues, 11. Lacks, 12. Professional development needs.

\section{Category Professional Identity.}

Intended as the area within which I define "who I am and what I am able to do in terms of knowledge and competences"

\begin{tabular}{|l}
\hline Teachers define themselves as: \\
\hline - "means" (1)7 \\
- "point of reference" (1) \\
- "medidge" (1) \\
- "harbor" (1) \\
\multicolumn{1}{c}{ Knowledge (11) } \\
- specific for the disciplinary area; \\
- a repertory of methodologies and \\
strategies to use according to the \\
learning difficulties of the students (with \\
and without disabilities ).
\end{tabular}

The teachers for special needs acknowledge themselves as capable to move in different fields through actions of contact and participation therefore they:

- perform an uintermediary» function (cfr. Wenger, 2006).

- live «an experience of multiple belonging» (Ivi).

- move along internal, boundary and peripheral trajectories (Ivi).

7 The number of interviews indicating the category described. 


\begin{tabular}{|c|c|}
\hline \multicolumn{2}{|c|}{$\begin{array}{l}\text { 2. Category Role. } \\
\text { The focus is on the tasks, i.e. on "what I do and how I perform my professional } \\
\text { identity within a context" }\end{array}$} \\
\hline $\begin{array}{l}\text { The teachers for special needs perform the } \\
\text { role of: }\end{array}$ & $\begin{array}{l}\text { The educational actions are situated and } \\
\text { aimed at: }\end{array}$ \\
\hline $\begin{array}{l}\text { - Intermediaries between the cognitive } \\
\text { and emotional needs of the students } \\
\text { with special needs and the requests of } \\
\text { the school contex (curricular teachers } \\
\text { and class). } \\
\text { - Intermediaries between the requests of } \\
\text { the family and the requests of the } \\
\text { school as institution; } \\
\text { - Intermediaries between the school } \\
\text { contents and the students with special } \\
\text { needs; } \\
\text { - Psychological support in situations of } \\
\text { cognitive, emotional and social distress } \\
\text { for all the students (11). }\end{array}$ & $\begin{array}{l}\text { - the acknowledgment and the } \\
\text { awareness of the resources and } \\
\text { potentialities both of the students with } \\
\text { special needs and of their families; } \\
\text { - the creation of appropriate conditions } \\
\text { for the development of autonomy in } \\
\text { students with special needs; } \\
\text { - the construction of a dialogic and } \\
\text { meditational space with the students } \\
\text { with special needs and their families; } \\
\text { - to support and calibrate the learning } \\
\text { pathways for students with special } \\
\text { needs, } \\
\text { - to differentiate and enlarge the } \\
\text { strategies to adopt in order to support } \\
\text { the students with special needs in their } \\
\text { learning processes; } \\
\text { - to negotiate with the curricular } \\
\text { colleagues strategies of interaction, } \\
\text { assessment and evaluation with and } \\
\text { for the students for special needs; } \\
\text { - to listen to the different problems and } \\
\text { difficulties of all the students (11). }\end{array}$ \\
\hline
\end{tabular}

\section{Category Motivation}

The choice to become a teacher for special needs is determined by:

1. A personal interest towards some areas and some forms of knowledge (5);

2. An occupational need (7).

\section{Category Feelings and emotions}

The emotional sphere is organized and divided into two areas:

1. The direct relationship with the students with special needs is experienced in positive, peaceful and fulfilling way (9):

2. The non-recognition of their own professional identity within everyday educational practices generates feelings of delusion and frustration (6). 


\section{Category Representations and linguistic uses}

Terminology used by teachers for special needs to refer to students with special needs

- Students with diverse abilities (1);

- Students with Down syndrome (1);

- Students with functional diagnosis of light or medium mental retardation (1):

- Handicapped students (1);

- my boy (1);

- a Down boy/girl; a Down (3);

- students with problems due to their handicap (1);

- students with learning disabilities (1);

- disabled student (1);

- $\quad$ student needing special support (1);

- handicapped boy(1);

- boys in condition of disability (1).

\section{Category Reflective practice}

Professional practice (technical rationality): $\quad$ Reflective practice (reflective rationality) (cfr. Schön, 2006):

- Reconnaissance of the personal and academic story of the student with special needs;

- Self-introduction to the class,

- Direct acquaintance with the students with special needs and their

- Challenging oneself

- questions

- doubts

- evaluation observation;

- analysis of the constrains (11).

- Choice, design and organization of a personalized educational plan.

\section{Category Relationship with the families}

The teachers for special needs say that it is fundamental:

1) to establish a good relationship with the families in order to facilitate the educational pathways for the students with special needs (8);

2) the need of a reciprocity in the relationship with the families of the students (7).

The construction of a relationship with the families of the students is developed in a peripheral action area, around actions aimed at connecting the centre-represented by the cognitive requests of the school- and the periphery represented by the emotional needs of the families. 
La construcción de la identidad profesional del profesorado de Educación Especial de Enseñanza Secundaria en Italia. Un estudio en la zona de Nápoles

\section{Category Professional practice}

The professional practice is articulated into the following phases:

First phase: recognition of the personal and academic story of the student with special need.

Second phase: self-introduction as "teacher to support the class" and direct acquaintance with the students with special needs;

Third phase: observation of the students with special needs.

Fourth phase: choice and organization of an individualized educational plan.

\begin{tabular}{|c|c|}
\hline $\lg (11)$ & $\lg (11)$ \\
\hline $\begin{array}{l}\text { We are facing the most severe or } \\
\text { problematic cases, which require the } \\
\text { development of an individualized plan, } \\
\text { that should be discussed and agreed } \\
\text { upon with all the teachers of the class, the } \\
\text { Sanitary Assistance, and the family of the } \\
\text { students for special needs but is generally } \\
\text { acknowledged as the responsibility of the } \\
\text { teachers for special needs; } \\
\text { - During class support activities the } \\
\text { teacher for special needs is generally } \\
\text { working near the student; } \\
\text { - In the educational work done with the } \\
\text { students the primary objective is the } \\
\text { personal and social autonomy of the } \\
\text { same; } \\
\text { - teachers build learning paths that }\end{array}$ & $\begin{array}{l}\text { On of the } \\
\text { s fixed by the } \\
\text { achers for special } \\
\text { s working near the } \\
\text { i needs and there } \\
\text { to the learning } \\
\text { whole class; } \\
\text { rk carried out with } \\
\text { ecial needs is } \\
\text { ninimum targets; } \\
\text { needs develop } \\
\text { ort the learning } \\
\text { sse of specific } \\
\text { oncept maps, } \\
\text { and }\end{array}$ \\
\hline
\end{tabular}
make use of situated tools and teaching strategies.

In both cases teachers for special need emphasize:

- The construction of an educational relationship with the students is developed through transversal actions which involve all the students in the class;

- The planning of the learning targets to reach for the academic success of the students with special needs;

- Part of the educational work is planned and organized at home: teachers for special needs get information regarding the pathologies, build up facilitated learning pathways, construct learning sheets, conceptual maps, questionnaires;

- The educational actions and strategies are a work in progress, and are therefore continuously experimented on the field, "in action" ;

- The educational work is mainly performed in the classroom, in exceptional circumstances the students are allowed to work with the teacher for special needs outside the class.

- Teachers for special needs make use of specific materials and tools to support the students with special needs according to their difficulties;

- Teachers for special needs inform the colleagues and the class about the leaning and relational problems of the students with special needs in order to support their inclusion. 


\section{Category Relationship with the colleagues}

The relationship with the colleagues is developed around two main areas:

1) The perception of a non-recognition of ones' own processional identity and expertise by the other colleagues working within the curriculum (9).

The practice and jurisdictional regime of the teachers for special needs become "the source of their border," because:

- teachers for special needs develop a repertoire of practices different from the ones used by the regular teachers;

- teachers for special needs have a more detailed and complex vision of their educational practice (involving knowledge, languages, methodological strategies and specific tools) that the regular teachers seem to have not.
2) The negotiation of languages, tools, strategies with the regular teachers and the other teachers for special needs (11).

The relationship between teachers for special needs and the regular teachers sustain the development of a 'practice boundary' (see Wenger, 2006) through "a form of collective mediation" which reflects the need to re-negotiate their meaning perspectives (see Mezirow, 2003) and use 'boundaries and peripheries' of their own practice in order to build a relationship between colleagues aimed at the welfare of the students with special needs. Such trading is influenced by relationships of "ownership of meaning" (cf. Wenger, 2006)

The relationship among teachers for special needs is generated by a tension between identification and negotiability, i.e., the same process that unifies and creates a community of practices (identification), also originates a conflict "an economy of meaning by the generation of something to negotiate "(Ivi). Even in this case, the negotiation is influenced by relationships of "ownership of meaning" (ibid.).

\section{Category Lacks}

- The lack of appropriate spaces and technological tools useful to cope with the special needs of the students generate the difficulty to perform effective educational practices and is therefore frustrating (6).

As a consequence, the professional practice of the students for special needs is "constantly reinvented even if it remains the same practice» and it is "at the same time highly uncanny and highly resilient $॥$ (cfr. Wenger, 2006). 


\section{Cathegory Professional Development needs}

According to the teachers for special needs it is necessary:

1. to have the opportunity to access free professional development courses held at the school where they work(10);

2. to have the possibility to confront their own professional experiences with colleagues and experts (7).

\section{DISCUSSION OF THE RESEARCH OUTCOMES}

Due to the complexity of the educational context and of the students' needs the professional identity of the teacher for special needs is constantly negotiated and constructed through various contact actions and forms of participation which have a reciprocal influence since they require coordination and reconciliation (Wenger, 1998;2002). In fact, the different practices in which the teacher for special needs is involved require the construction of a professional identity that develops along multiple trajectories intended as movements, choices and actions within the relationships with the students with disabilities, their families and the teacher's colleagues. For these reasons the construction of professional identity is a work in progress and is defined according to the interaction, that is to say the "nexus", between internal, borderline and peripheral trajectories. All the movements, actions and choices referring to the educational practice (the internal trajectories), all the movements, actions and choices referring to the negotiation of meaning between a community of practices and the others, such as, for example, regular teachers, and socio-sanitary operators (the border line trajectories) and all the movements, actions and choices which are not leading towards a full participation in all the different communities of practice but that somehow provide access to one community and to its practices, such as, for example, the community of the regular teachers or of the families (the peripheral trajectories) have a deep impact on the professional identity and on the practices of the teacher for special needs.

In both phases of the study (the macro and micro phase) for the majority of the teachers, the choice to become a teacher for special needs was determined by an employment opportunity (since in Italy this is the main pathway to a tenured position). Motivation is therefore a first critical node in the construction of the professional profile of the teacher for special needs. This choice is frequently an alternative, secondary and in some way forced choice if compared with original expectations and life projects but after a while the teachers are challenged to rethink 
critically their profession and come to re-frame their meaning perspectives through their relationship with disabled students.

The outcomes of the two phases are consistent and highlight the presence of a positive and rewarding relationship between teachers and disabled students. Success and well-being are the final goal of the educational agency of the teachers for special needs and therefore the relationships that the teachers are able to build up and keep with all the actors participating at different levels in the cultural and social life of disabled students are extremely important. The teacher for special needs is therefore an "intermediary agent" able to connect both to the cognitive and affective needs of the disabled students and their families as well as to the requirements and resources of the school system, activating processes of "translation, coordination and alignment" among the meaning perspectives of all the actors involved in the educational process.

More precisely, the teacher for special needs plays the following roles:

- intermediary agent between the cognitive and affective needs of the disabled students and the requirements of the school context (teachers and classes);

- intermediary agent between the demands of the family and those of the school;

- intermediary agent between the disciplinary contents and the disabled students;

- psychological support in situations of cognitive, emotional and social discomfort for all the students.

The didactic actions are situated in and directed towards:

- the acknowledgment and awareness of the resources and potentialities of the disabled students and their families;

- the creation of the proper conditions to develop autonomy in the disabled students;

- the construction of a dialogue and mediation space for the disabled students and their families;

- the possibility to support and calibrate the learning pathways for disabled students;

- the diversification and widening of the strategies used to cope with the learning needs of the disabled students;

- the negotiation, together with other teachers, of special forms of interaction, assessment and evaluation with and for the disabled students; 
- the possibility to listen to the problems and to take care of the different difficulties of all the students in the class.

The knowledge includes:

- Specific knowledge related to the disciplinary area;

- A repertory of methodologies and strategies to use according to the learning difficulties of the students (whether or not disabled).

The competences are:

- technical and design oriented;

- didactic and methodological;

- communicative and socio-relational.

Both the knowledge and competences are constantly rearticulated in the field and in action.

Professional practice is changing and differentiated, and therefore leads towards a flexible professional identity, able to adjust itself to different scenarios and therefore attentive to changes. This practice is organized in four phases:

1) recognition of the personal and academic history of the disabled student;

2) self-introduction to the class and to the student with a disability;

3) observation;

4) choice and organization of an individualized educational plan for the disabled student.

Both in the first phase as well as in the interviews we have identified the:

- Use of different interpretative categories of disability;

- Use of differentiated practices according to different educational pathways (e.g. a student follows a very different learning pathway compared to the class or a pathway regulated on the minimum learning objectives for all the class).

In the first case:

- the teachers are facing students with serious learning difficulties which require the development of an individualized learning plan which should be designed and 
planned with all the teachers of the class, with the experts of the local health center and with the family of the students. However, frequently this becomes the task of the teacher for special needs alone. Only later and occasionally are the other teachers involved.

- during the classes the teachers for special needs sit near the disabled students;

- the first educational goal is the achievement of personal and social autonomy;

- the learning processes are supported by situated didactic strategies.

To summarize, when teachers are confronted with students requiring a differentiated learning plan, they tend to use most frequently practices that are peripheral to the educational work involving the whole class. This condition impacts dramatically on the professional identity and role of the teacher since the pair (the teacher for special needs and the disabled student) are isolated from the class. The disabled student is no longer perceived as a class student but as the "student of" the teacher for special needs, and the teacher for special needs is not considered as a teacher for the class. This generates forms of exclusion and marginalization which is the second critical node in the development of the professional identity of the teachers.

Teachers for special needs try to offer to the educational context a professional profile functional to support the whole class but the intermediation function between the various parts of the school system is hardly perceived and appreciated by the regular teachers and the class, who tend to consider the teacher for special needs only in reference to the needs of a specific disabled student. This is why, coherently with the data collected in the first phase of the study, the teacher for special needs is continuously challenged to affirm his/her professional identity and to negotiate his/her role; moreover, the difficulties that he/she encounters in his/her work are not taken into account by the regular teachers. The different professional languages used, and the different understandings of the didactic work, create a deep division between the two communities of practice (regular teachers versus teachers for special needs) within the school system. The perception is that there is a separation between the regular teachers and the teachers for special needs and this represents a third critical node in the development of the professional identity since this situation generates in the teachers for special needs feelings of not belonging to the same professional category, of frustration, disillusionment, resignation, rage and professional dissatisfaction. 
A significant part of the professional agency is constructed on the basis of "personal knowledge", that is to say a repertory of tacit knowledge which bring an "operational power" (de Mennato, 2003) and therefore contributes to the construction of the professional epistemology of the teachers for special needs. The "personal practical knowledge" (cfr. Connelly \& Clandinin, 1997) becomes a resource because it represents an additional form of knowledge which, through reflective devices (cfr. Schön, 1986), helps in orienting and re-organizing the educational actions within a complex professional context.

We see, therefore, that within the context of professional practice teachers for special needs activate a personal reflective space (reflective practice) which allows them to:

- Trace back and question the practice, choices, and emotional states;

- Carry out a recognition of the facts and actions in order to redesign their actions.

The elements and actors of the school system that have a deep influence on the role and the professional practice of the teachers for special needs are, according to our study:

- the relationships with the families;

- the relationships with their colleagues;

- the lack of spaces and technological tools useful to cope with the needs of the disabled students..

As highlighted in both phases of the study, the teacher for special needs structures his/her role and optimizes his/her professional practice through the search for a communicative channel and an mutual involvement with the families and his/her colleagues.

The following activities therefore become strategic:

- the realization of "areas of peripheral action» with the family;

- the activation of «borderline practices» with the regular teachers;

- the identification and negotiation of professional shared spaces with the other teachers for special needs.

The lack/or presence of these elements has a deep impact on the role and on professional practice. In particular, the lack of suitable spaces and of technological tools to cope with the educational and didactic needs of the disabled students represents a fourth critical node for the professional activity of the teachers for special needs. 
This enhances the role of a professional who performs an intermediary function, developing specific and situated answers through the capacity to reinvent professional practice even if it remains the same when fundamental resources and tools are not available.

\section{The training and professional development needs involve:}

- the possibility to have access to free professional development courses activated inside the school;

- the possibility to share and compare their professional experiences with other colleagues and experts.

Teachers for special needs acknowledge the need for an external support through continuous training and field experience involving school and different expertise and professionalities.

For this reason, the outcomes of the first phase of the study, which highlighted the tendency to understand their profession as very specific and structured, not possibly evolving through training and professional development, acquires a new meaning since it appears that the teachers are likely to be involved in new and different forms of professional development, responding to complex professional needs, strongly connected to everyday experience and professional practice, which touch the "indeterminate zones" of practice -- uncertainty, complexity, uniqueness conflict -- which fall outside the categories of technical rationality) (Schön,1986). The teacher for special needs is therefore a professional potentially ready for change, open to the questioning of his/her educational acting and «personal practical knowledgen, since he/she is aware of the importance of others' educational and professional experiences, and entrusts his/her own professional development to reflective devices, dialogue, narrative and the sharing of languages, methods and strategies. He/she is a professional who needs to:

- reflect on his/her own methodologies and educational strategies;

- reflect on his/her own emotions and feelings;

- reflect on the interpretative categories used to approach and define disability;

- have at his/her disposal an open and shared space-time (narrative community);

- have more "borderline meetings" with the regular teachers;

- go visiting other practices;

- negotiate new solutions; and

- rethink himself/herself as a new professional. 
For these reasons, the lack of the opportunity of a continuing training on the job can be seen as another critical node for this profession.

This last fifth critical point, together with the isolation of the teacher for special needs / student with disability pair with a differentiated learning plan, the separation between teachers for special needs and regular teachers, the lack of adequate learning spaces and technological tools.

\section{CONCLUSIONS}

All the critical nodes highlight the absence or lack of some indicators of inclusion that are at the basis of the Inclusion Index (cfr. Booth \& Ainscow, 2000, 2002, 2011) as indicated in the following scheme.

\begin{tabular}{|c|}
\hline $\begin{array}{l}\text { Dimension A. Creating inclusive cultures. Section A1. Building up } \\
\text { communities }\end{array}$ \\
\hline A.1.3 Teachers collaborate with each other. \\
\hline $\begin{array}{l}\text { Dimension A. Creating inclusive cultures - Section A.2 Affirm inclusive } \\
\text { values }\end{array}$ \\
\hline $\begin{array}{l}\text { A.2.2 Teaching staff, the school council, students and families } \\
\text { share an inclusive philosophy. }\end{array}$ \\
\hline $\begin{array}{l}\text { Dimension B. Producing inclusive policies- Section B.1 Developing a } \\
\text { school for all }\end{array}$ \\
\hline B.1.4 The school makes its structures accessible to all people. \\
\hline $\begin{array}{l}\text { Dimension B. Producing inclusive policies- Section B.2 Organizing } \\
\text { support for diversity }\end{array}$ \\
\hline $\begin{array}{l}\text { B.2.2 The training activities help the teachers to face the diversity } \\
\text { of the students. }\end{array}$ \\
\hline $\begin{array}{l}\text { B.2.6 Policies of personal and behavioral support are connected } \\
\text { to policies supporting curricular development and learning. }\end{array}$ \\
\hline $\begin{array}{l}\text { B.2.7 Reduction of the practices exclusive from the curricular } \\
\text { activities in the class. }\end{array}$ \\
\hline $\begin{array}{l}\text { Dimension C. Developing inclusive practices }- \text { Section C.1 } \\
\text { Coordinating learning }\end{array}$ \\
\hline C.18 Teachers collaborate in planning, teaching and evaluation. \\
\hline $\begin{array}{l}\text { C.1.9 Teachers for special needs support learning and } \\
\text { participation for all the students. }\end{array}$ \\
\hline Section C.2 Mobilize resources \\
\hline C.2.2 Teachers' competences are used in the best way possible. \\
\hline $\begin{array}{l}\text { C.2.5 School resources are equally distributed in order to support } \\
\text { inclusion. }\end{array}$ \\
\hline
\end{tabular}


Indeed, the transversal analysis of the three dimensions and the relative sections paired with the outcomes of the research highlight the paradoxical condition of exclusion of the teacher for special needs within the context of a professional practice which claims and strives to be inclusive.

This paradox determines the difficulty to develop an effective system for the integration/inclusion of the students with special needs as far as the teachers for special needs are not considered as system resources as they should be but are forced to perform an ambiguous role, which jeopardizes their professional identity and limits their field of action within the educational scene.

\section{REFERENCES}

\section{Norms and legislative documents}

Law 30th March 1971, n. 118, Nuove norme in favore dei mutilati ed invalidi civili, Art. 5.

Ministry of Public Instruction "Relazione conclusiva della Commissione Falcucci concernente i problemi scolastici degli alunni handicappati", 1975.

Law 4th August 1977, n. 517, Norme sulla valutazione degli alunni e sull'abolizione degli esami di riparazione nonché altre norme di modifica dell'ordinamento scolastico, Artt. 2, 7.

Law 5th February 1992, n. 104, Legge quadro per l'assistenza, l'integrazione sociale e i diritti delle persone handicappate, Artt. $12,13,14,15$.

D.P.R. 24th February 1994, Atto di indirizzo e coordinamento relativo ai compiti delle unità sanitarie locali in materia di alunni portatori di handicap, Artt.4 e 5.

Ministry of Instruction, University and Research, Linee guida per l'integrazione scolastica degli alunni con disabilità, 4th August 2009.

Law 8th October 2010, n. 170, Nuove norme in materia di disturbi specifici di apprendimento in ambito scolastico.

D.M. 27th December 2012, Strumenti di intervento per gli alunni con Bisogni Educativi Speciali e organizzazione territoriale per l'inclusione scolastica. 


\section{Studies and research projects}

ALEIHT, P.; BERGAMINI S. (1996). Storie di vita. Metodologia di ricerca per le scienze sociali. Milano: Guerini Studio.

ATKINSON, R. (1998). The life story interview, Thousand Oaks, Ca: Sage.

BOOTH, T. and AINSCOW M. (2000, 2002, 2011) Index for Inclusion: developing learning and participation in schools, Bristol: CSIE.

BRUNER J. (1986), Actual Minds, Possible Worlds,Harvard, Mass: Harvard University Press.

BRUNER J. (1990), Acts of Meaning, Harvard, Mass: Harvard University Press

BRUNER J. (1996), The Culture of Education, Harvard, Mass: Harvard University Press.

CANEVARO, A., D'ALONZO, L., IANES, D., \& CALDIN, R. (2011). L'integrazione scolastica nella percezione degli insegnanti. Trento: Erickson.

CONNELLY F. M; CLANDININ, D. J.and HE. M. F. (1997). Teachers' personal practical knowledge on the professional knowledge landscape in Teaching and Teacher Education, 13 (7), 665-674.

DE PABLOS PONS J.; GONZÁLEZ PERÉZ A. (2012), El bienestar subjetivo y las emociones en la enseñanza in Revista Fuentes, (Sevilla) 12, pp. 69-92

D'Alessio S. (2011), Inclusive Education in Italy. A Critical Analysis of the Policy of Integrazione Scolastica, Rotterdam: Sense Publishing.

D.O.I.: http://dx.doi.org/10.1007/978-94-6091-342-6

DE MENNATO, P. (2003). II sapere personale. Un'epistemologia della professione docente. Milano: Guerini Scientifica.

FARR, R.M.; MOSCOVICl, S. (Eds.) (1984). Social Representations. Cambridge, United Kingdom: Cambridge University Press.

FONDAZIONE TREELLE (2011), Gli alunni con disabilità nella scuola italiana: bilancio e proposte. http://www.treellle.org/pubblicazioni (consulted on june the 26th).

GARCÍA C. H., Bienestar docente y pensamiento emocional (2012), in Revista Fuentes (Sevilla), 12, pp. 47-68

GATTICO, E.; MANTOVANI S. (Eds.). (1998). La ricerca sul campo in educazione: Vol. 2: I metodi quantitativi. Milano: Mondadori.

MANTOVANI, S. (1998). La ricerca sul campo in educazione: Vol.1: I metodi qualitativi. Milano: Mondadori.

MILES M.B.; HUBERMAN A.M. (1994), Qualitative Data Analysis: An Expanded Sourcebook, London: Sage.

MOE', A.; PAZZAGLIA and F. FRISO G. (2010). MESI - Motivazioni, Emozioni, Strategie e Insegnamento. Questionari metacognitivi per insegnanti. Trento: Centro Studi Erickson. 
REBOLLO M.A.; GONZALEZ E. AND GARCIA M.R., (2001), Identidades profesionales en educación desde una perspectiva de género in Revista Fuentes. Volumen 3, pp. 117-13.

SCHÖN, D.A. (1987). Educating the reflective practitioner. Toward A New Design For Teaching And Learning, San Francisco: Jossey Bass.

SITA', C. (2012). Indagare l'esperienza, L'intervista fenomenologica nella ricerca educativa. Roma: Carocci.

SPSS Inc. (1999). SPSS Base 10.0 for Windows User' s Guide. Chicago IL.

STRIANO, M. (2005). La narrazione come dispositivo conoscitivo ed ermeneutico in Pratiche narrative per la formazione, M@gm@, Vol.3, n 3, pp.17-20 [consulted on June the 26th2014)] http://www.analisiqualitativa.com/magma/0303/articolo_01.htm

STROLLO, M.R. (Ed.). (2014). La motivazione nel contesto scolastico. Percorsi di ricerca e prospettive di intervento pedagogico nel territorio della Campania. Milano: FrancoAngeli.

VIGANO', R. (2002). Pedagogia e sperimentazione. Metodi e strumenti per la ricerca educativa. Milano: Vita e Pensiero.

WENGER, E. (1998). Communities of Practice: Learning, Meaning, and Identity. Cambridge: Cambridge University Press. D.O.I.: http://dx.doi.org/10.1017/CBO9780511803932

WENGER, E.; MCDERMOTT R. and SNYDER, W. M. (2002). Cultivating Communities of Practice (Hardcover). Harvard Business Press; 1 edition. 


\section{Sobre los autores:}

\section{Maura striano}

maura.striano@unina.it

Maura Striano is full professor of Pedagogy at the University of Naples Federico II, Department of Humanities.

\section{Elisabetta Grieco}

Elisabetta Grieco is Phd in Psychological and Pedagogical Sciences at the University of Naples Federico II

\section{Para citar este artículo:}

Striano, M. y Grieco, E. (2014). La construcción de la identidad profesional del profesorado de educación especial de enseñanza secundaria en Italia. Un estudio en la zona de Nápoles. Revista Fuentes, 15, Junio, pp. 113-142. [Fecha de consulta: dd/mm/aaaa]. http://www.revistafuentes.es/

D.O.I.: http://dx.doi.org/10.12795/revistafuentes.2014.115.06 